\title{
Spectrophotometric determination of trifluoperazine via oxidative coupling reaction with sulfanilic acid
}

\author{
Theia'a N. Al-Sabha \\ Department of Chemistry / College of Education \\ Mosul University \\ Maha T. Al-Obidi \\ Department of Chemistry / College of Science \\ Mosul University
}

Omar A. Al-Taee

Received

$18 / 01 / 2009$
Accepted

25 / 02 / 2009

\section{الملغص}

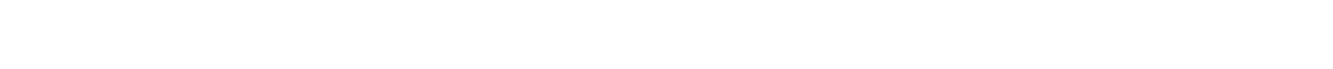

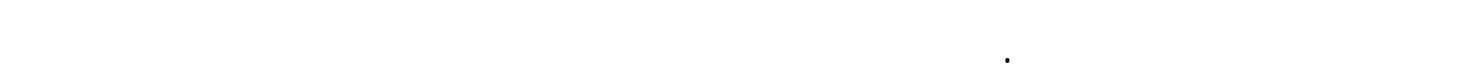

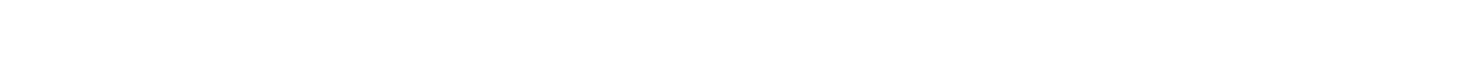

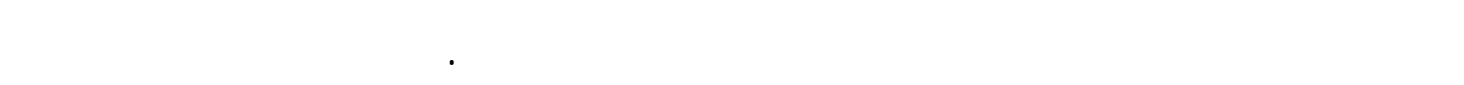

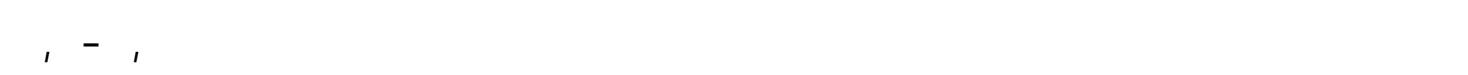

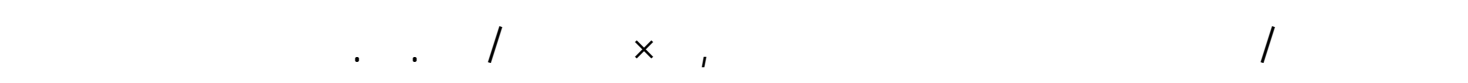

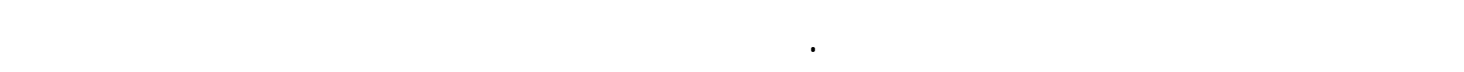

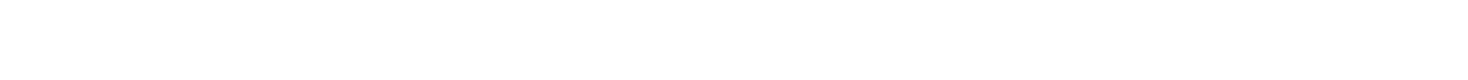
الهستور البريطاني وخالية من تدلخل مواد اللسواغ.

\section{Abstract}

A simple spectrophotometric method has been developed for the determination of trifluoperazine hydrochloride in pure and in dosage forms. The method is based on the oxidative coupling reaction with sulfanilic acid in the presence of sodium hypochlorite in acetic acid medium to give an red coloured product with absorption maximum at 510 $\mathrm{nm}$. The product is stable for more than $6 \mathrm{~h}$. Beer's law is obeyed over the concentration range of $0.2-7.0 \mu \mathrm{g} \mathrm{ml}^{-1}$ with molar absorptivity of 
$5.15 \times 10^{3} 1 . \mathrm{mol}^{-1} \mathrm{~cm}^{-1}$. Different experimental parameters affecting the development and stability of the formed coloured product were carefully studied and optimized and a proposal of the reaction pathway was presented. The proposed method was applied successfully to the determination of trifluoperazine hydrochloride in tablets and compared favorably with the official method. Common excipients used as additives in pharmaceutical preparations do not interfere in the proposed method.

Keywords: Trifluoperazine hydrochloride, oxidative coupling, sulfanilic acid, spectrophotometry.

\section{Introduction}

Trifluoperazine hydrochloride (10-[3-(4-methyl-1-piperazinyl) propyl]-2-trifluoro-methylphenothizine dihydrochloride) (I) is a typical antipsychotic drug of the phenothiazine group. It has a central antiadrenergic, antidopaminergic, minimal anticholinergic effects and commonly used antipsychotic drug ${ }^{[1]}$. It has been known to induce QT prolongation and ventricular tachycardia, which can cause sudden death ${ }^{[2]}$ and hence is used in the treatment of various mental illnesses such as schizophrenia..

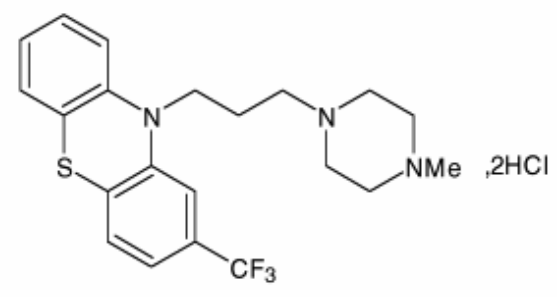

( I ) $\quad$ Mwt $=\mathbf{4 0 7 . 4 9 7}$

The importance of trifluoperazine has prompted many investigators to look for methods for its rapid determination. The official method is based on non-aqueous titration of the pure drug or its dosage forms ${ }^{[3]}$. Many titrimetric methods based on oxidation by oxidizing agents such as hexacyanoferrate ${ }^{[4]}$, ammonium metavanadate ${ }^{[5]}$, N-bromosuccinimide and other brominating agents ${ }^{[6]}$ and 1-chlorobenzotriazole ${ }^{[7]}$ have been proposed. Most other methods are based on oxidation prior to analytical measurement. Typical oxidants used are potassium iodate ${ }^{[8]}$, ammonium molybdate $^{[9]}$, ammonium metavanadate ${ }^{[10]}$, hexacyanoferrate(III $)^{[11]}$, nitroprusside ${ }^{[12]}$, N-bromophthalimide ${ }^{[13]}$ iron (III) chloride ${ }^{[14]}$ and iodic $\operatorname{acid}^{[15]}$ and the final products are determined spectrophotometrically. Spectrofluorimetry has been used after oxidation by $\mathrm{N}$ bromosuccinimide $^{[16]}$ and cerium(IV) $)^{[17]}$. Also potentiometry ${ }^{[18]}$ with an oxidative column in a flow injection system has been applied. Highperformance liquid chromatography (HPLC) ${ }^{[19]}$ with electrochemical 
detection has been proposed for the determination of phenothiazines in pharmaceuticals and human serum. Other methods proposed for the assay of phenothiazines include potentiometry ${ }^{[20,21]}$, voltammetry ${ }^{[22,23]}$, deferential spectrophotometry ${ }^{[24]}$ and chemiluminescene spectroscopy $[25,26]$

In this work, a spectrophotometric method for the determination of trifluoperazine hydrochloride is proposed and based on its oxidation by sodium hypochlorite followed by coupling with sulfanilic acid in the presence of acetic acid, The proposed method was applied to determine trifluoperazine hydrochloride in tablets as drug formulations. A satisfactory results were obtained in comparison with official method.

\section{Experimental}

\section{Apparatus}

All absorption measurements were carried out on a Shimadzu UV210A double - beam spectrophotometer supplied with a digital printer DP80Z and matched 1-cm optical silica cells.

\section{Reagents}

All chemicals used were of analytical reagent grade, the pure trifluoperazine hydrochloride was provided from State Company for Drug Industries and Medical Appliance-(SDI) Sammara-Iraq.

\section{Trifluoperazine hydrochloride $(1000 \mu \mathrm{g} / \mathrm{ml})$}

A stock solution of $1000 \mu \mathrm{g} / \mathrm{ml}$ of trifluoperazine hydrochloride was prepared by dissolving of $0.1 \mathrm{~g}$ in distilled water and then made up to $100 \mathrm{ml}$ in volumetric flask with the same solvent. The working solution of $100 \mu \mathrm{g} / \mathrm{ml}$ was prepared by simple dilution of stock solution and kept protected from sun light in ambient bottle.

\section{Sulfanilic acid $\left(4 \times 10^{-3} \mathrm{M}\right)$}

This solution was prepared by dissolving $0.11 \mathrm{~g}$ of sulfanilic acid reagent in distilled water and diluted to the mark in $1 \mathrm{~L}$ volumetric flask with the same solvent.

\section{Sodium hypochlorite $(0.1 \% \mathrm{v} / \mathrm{v})$}

This solution was prepared by dilution of $1.25 \mathrm{ml}$ of $8 \%$ sodium hypochlorite to $100 \mathrm{ml}$ with distilled water in a volumetric flask.

\section{Acetic acid (3.5\% w/v)}

This solution was prepared by dilution of $3.5 \mathrm{~g}$ of glacial acetic acid to $100 \mathrm{ml}$ with distilled water in a volumetric flask. 


\section{Recommended procedure}

Aliquots of standard solution of trifluoperazine hydrochloride covering the range $(1.25-175 \mu \mathrm{g})$ were transferred to a $25-\mathrm{ml}$ calibrated flasks containing $5 \mathrm{ml}$ of $4 \times 10^{-3} \mathrm{M}$ sulfanilic acid solution, $3 \mathrm{ml}$ of $0.1 \%$ sodium hypochlorite and $1.0 \mathrm{ml}$ of $3.5 \%$ acetic acid, then the solutions were made up to the mark with distilled water and left for $10 \mathrm{~min}$. The absorbance was measured at $510 \mathrm{~nm}$ against reagent blank.

\section{Analysis of Tablets}

Twenty five tablets (each tablet containing $1 \mathrm{mg}$ ) or five tablets (each tablet containing 5mg) were weighed and finely powdered. An amount of the powder equivalent to $5 \mathrm{mg}$ of pure drug of trifluoperazine hydrochloride was extracted with $5 \mathrm{ml}$ acetone, filtered and the filtrate evaporated to dryness. The residue was dissolved in a portion of distilled water and the volume was made up to $100 \mathrm{ml}$ in volumetric flask. The solution was kept in amber-coloured bottle and stored in a refrigerator. The solution was further diluted as needed.

\section{Results and discussion}

\section{Absorption spectra}

An orange-coloured oxidizing coupling product with an absorption maximum at $510 \mathrm{~nm}$ is formed when trifluoperazine hydrochloride was allowed to react with sulfanilic acid in the presence of sodium hypochlorite in acetic acid medium. Figure (1) shows the spectra of orange product formed and of the reagent blank, so; the maximum absorption at $510 \mathrm{~nm}$ is used in all subsequent experiments.

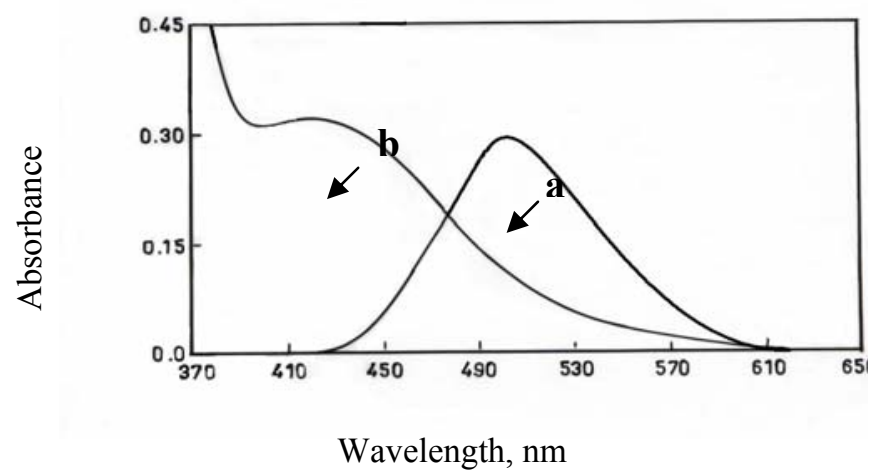

Fig.1 Absorption spectra of (a) $75 \mu \mathrm{g}$ trifluoperazine hydrochloride with sulfanilic acid against reagent blank, and (b) reagent blank versus distilled water. 


\section{Study of the optimum reaction conditions}

The effect of various parameters on the absorption intensity of the dye formed was studied and the reaction conditions are optimized.

\section{Effect of acid}

It was found that the presence of acid led to an increase the intensity of the produced product, therefore some acids such as $\mathrm{HCl}$, $\mathrm{H}_{2} \mathrm{SO}_{4}$ and $\mathrm{CH}_{3} \mathrm{COOH}$ are examined and was found that all these acids gave almost equal intensity, so; $\mathrm{CH}_{3} \mathrm{COOH}$ was selected which was found that $1 \mathrm{ml}$ of this acid gave higher sensitivity and this amount was selected in subsequent experiments.

\section{Effect of sulfanilic acid}

When various concentrations of sulfanilic acid reagent solution were added to fixed amount of the drug solution, a $5 \mathrm{ml}$ of $4 \times 10^{-3} \mathrm{M}$ solution was found enough to develop the colour in its full intensity and gave a minimum blank value, therefore it was considered to be an optimum amount.

\section{Effect of oxidant concentration}

The product formation was reached its maximum intensity when 4$6 \mathrm{ml}$ of $0.1 \mathrm{M}$ of sodium hypochlorite solution were added to a mixture of trifluoperazine hydrochloride, sulfanilic acid and acetic acid, therefore 5 $\mathrm{ml}$ was selected in the procedure since it gives high sensitivity, minimum blank value and ensure a quantitative determination at the upper limit of the calibration graph.

\section{Effect of temperature and reaction time}

The reaction time was determined by following the colour development at room temperature and at different temperatures in thermostatically controlled water-bath. The absorbance was measured at $5 \mathrm{~min}$ intervals against reagent blank treated similarly. It was observed that formation of coloured complex for trifluoperazine Hydrochloride was achieved its maximum intensity after $10 \mathrm{~min}$ at room temperature and remain stable for at least 6 hours.

\section{Effect of order of addition}

To obtain optimum results the order of addition of reagents should be followed as given under the general procedure, otherwise a loss in colour intensity was observed.

\section{Calibration graph}

Employing the optimum conditions described in the recommended procedure, a linear calibration graph for trifluoperazine hydrochloride is obtained (Fig.2), which shows that Beer's law is obeyed over the 
concentration range of $0.2-7.0 \mu \mathrm{g} / \mathrm{ml}$ with correlation coefficient of 0.9998 and an intercept of 0.0451 . The conditional molar absorptivity of the red product formed was found to be $5.15 \times 10^{3} \mathrm{~L} \cdot \mathrm{mol}^{-1} \cdot \mathrm{cm}^{-1}$.

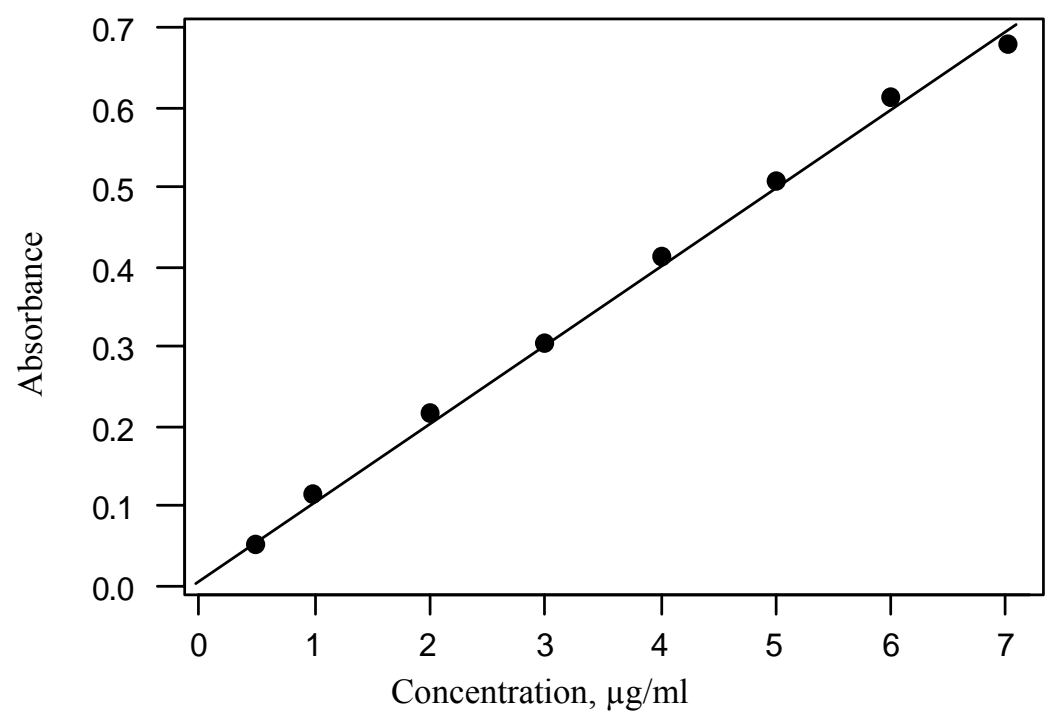

Fig.2 Calibration graph for determination of trifluoperazine hydrochloride

\section{Interference}

In order to assess the possible analytical applications of the proposed method, the effect of some foreign ions which often accompany with this drug in pharmaceutical products were studied by adding different amounts of foreign ions to $5 \mu \mathrm{g} / \mathrm{ml}$ of trifluoperazine hydrochloride. The colour was developed following the recommended procedure described earlier. Substance was considered to interfere with determination if the obtained absorbance values differed by more than $\pm 2 \%$ from that of the drug alone. It was observed that the talc, glucose, starch, sulfate, acetate, phosphate and magnesium stearate did not interfer with the determination at levels found in dosage form.

\section{Precision and accuracy}

Trifluoperazine hydrochloride was determined at three different concentrations. The results shown in Table (1), a satisfactory precision and accuracy has been obtained with the proposed method.

Table (1): Accuracy and precision of the proposed method

\begin{tabular}{|c|c|c|c|}
\hline $\begin{array}{l}\text { Amount of trifluoperazine } \\
\text { hydrochloride taken }(\mu \mathrm{g} / \mathrm{ml})\end{array}$ & $\begin{array}{c}\text { Recovery* } \\
\%\end{array}$ & $\begin{array}{l}\text { Average } \\
\text { recovery \% }\end{array}$ & $\begin{array}{l}\text { Relative standard } \\
\text { deviation* \% }\end{array}$ \\
\hline 1 & 99.1 & \multirow{3}{*}{$99,7 \pi$} & 0.81 \\
\hline 4 & 99.6 & & 1.63 \\
\hline 6 & 100.2 & & 1.08 \\
\hline
\end{tabular}




\section{Analytical application}

Tablets containing trifluoperazine hydrochloride have been analyzed and they showed good accuracy and precision, the results obtained were compared successfully with the official method (Table 2).

Table (2): Determination comparison of trifluoperazine Hydrochloride in tablets by the proposed method and British pharmacopoeia method

\begin{tabular}{|c|c|c|c|c|c|c|}
\hline $\begin{array}{l}\text { Procedure } \\
\text { applied }\end{array}$ & $\begin{array}{l}\text { Pharmaceutical } \\
\text { formulation }\end{array}$ & $\begin{array}{c}\text { Drug } \\
\text { amount } \\
\text { present } \\
(\mu \mathrm{g} / \mathrm{ml})\end{array}$ & $\begin{array}{l}\text { Recovery* } \\
(\%)\end{array}$ & $\begin{array}{l}\text { Drug } \\
\text { content } \\
\text { found } \\
\text { (mg) }\end{array}$ & $\begin{array}{l}\text { Average } \\
\text { Drug } \\
\text { content } \\
\text { found } \\
\text { (mg) }\end{array}$ & $\begin{array}{c}\text { Certified } \\
\text { value } \\
\text { (mg) }\end{array}$ \\
\hline \multirow{2}{*}{$\begin{array}{l}\text { Proposed } \\
\text { method }\end{array}$} & $\begin{array}{c}\text { Tablet }^{\mathrm{a}} \\
\text { (Iralzin 1) }\end{array}$ & $\begin{array}{c}0.5 \\
3 \\
6\end{array}$ & $\begin{array}{l}100.75 \\
101.37 \\
99.12\end{array}$ & $\begin{array}{l}1.007 \\
1.013 \\
0.991\end{array}$ & 1.003 & 1.0 \\
\hline & $\begin{array}{c}\text { Tablet }^{\mathrm{a}} \\
\text { (Iralzin 5) }\end{array}$ & $\begin{array}{c}0.5 \\
3 \\
6\end{array}$ & $\begin{array}{c}99.14 \\
100.18 \\
97.83\end{array}$ & $\begin{array}{l}4.957 \\
5.009 \\
4.891\end{array}$ & 4.952 & 5.0 \\
\hline $\begin{array}{c}\text { British } \\
\text { Pharmaco } \\
\text { poeia } \\
\text { method }^{[6]}\end{array}$ & Tablet & $\begin{array}{l}1 \mathrm{mg} \\
5 \mathrm{mg}\end{array}$ & $\begin{array}{l}99.61 \\
101.66\end{array}$ & $\begin{array}{l}0.980 \\
5.083\end{array}$ & - & $\begin{array}{c}1 \\
5.0\end{array}$ \\
\hline
\end{tabular}

* Mean of three determinations.

a Marketed by S.D.I, Iraq.

Statistical analysis of the results by Student's t-test (1.63) and Ftest (3.47) at 95\% confidence level showed no significant deference in accuracy and precision between the proposed and official method.

\section{Structure of the dye}

The stoichiometry of the reaction between trifluoperazine hydrochloride and sulfanilic acid was investigated applying the Job's method $^{[27]}$ and mole ratio method ${ }^{[28]}$ using equimolar solutions $\left(1 \times 10^{-4} \mathrm{M}\right)$ of drug and sulfanilic reagent. The results obtained, as shown in figure 3, indicated that the ratio of 1:2 drug to reagent complex was formed at $510 \mathrm{~nm}$.
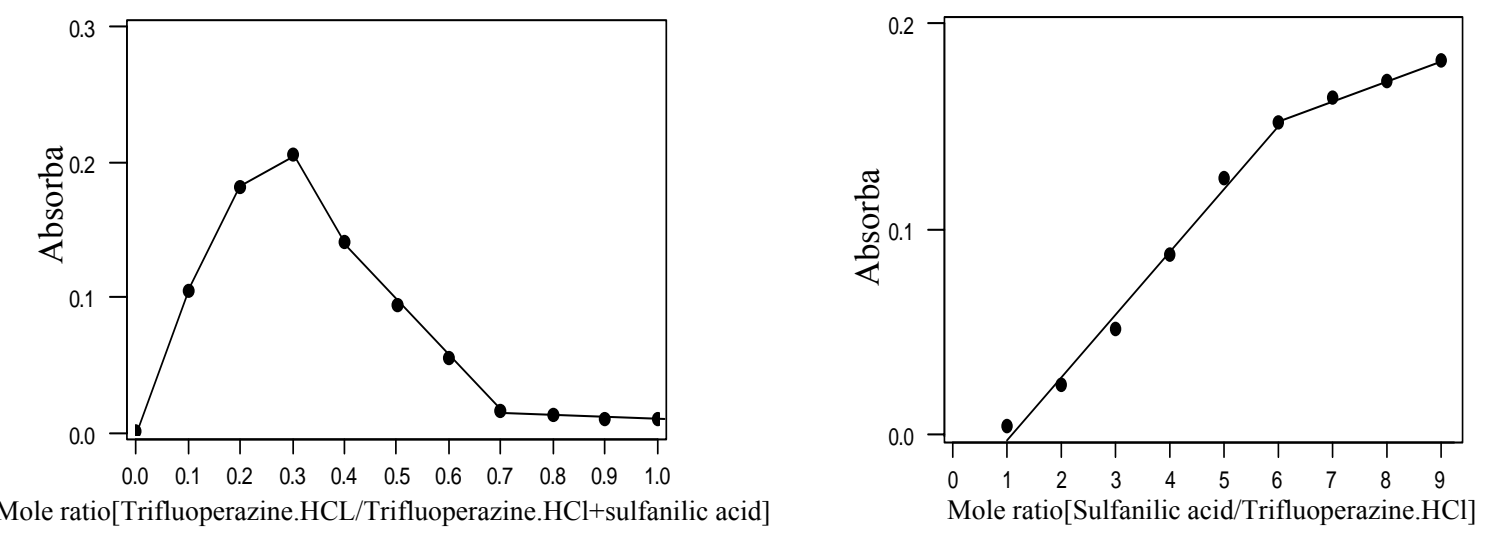

Fig.3: Job's plot method (a) and molar ratio method (b) of trifluoperazine hydrochloride - sulfanilic acid in the presence of $\mathrm{NaOCl}$. 
Therefore the formation of the product probably occurs as follows:
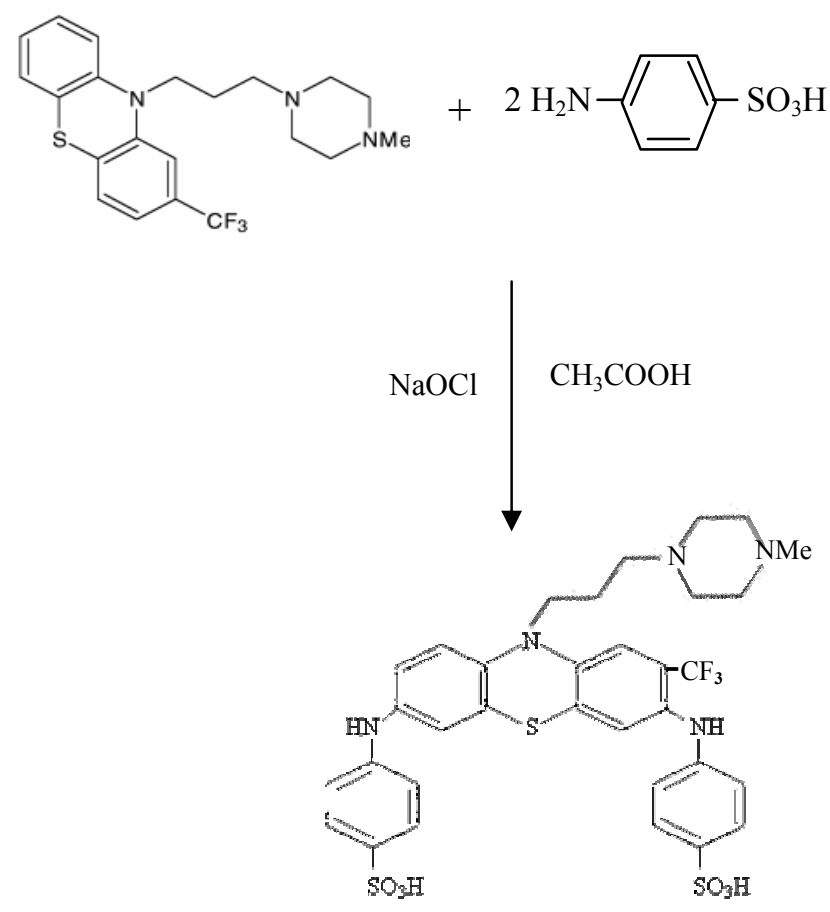

The product formed was water soluble, the stability constant was calculated by comparing the absorbance of a solution containing stoichiometric amount of trifluoperazine hydrochloride and sulfanilic acid with that of solution containing the optimum amount of sulfanilic acid (5 $\mathrm{ml}$ of $\left.4 \times 10^{-3} \mathrm{M}\right)$. The average conditional stability constant of the dye in water under the described experimental conditions was $1.2 \times 10^{8} 1^{2} \cdot \mathrm{mol}^{-2}$.

\section{Conclusions}

A simple, rapid, precise and sensitive spectrophotometric method has been developed for the determination of trace amounts of trifluoperazine.hydrochloride in aqueous solution based on its oxidative coupling reaction with sulfanilic acid and sodium hypochlorite in the presence of acetic acid. The proposed method does not require temperature control or the solvent extraction step; the method was applied successfully on pharmaceutical tablets.

\section{References}

1) http://en.wikipedia.org/wiki/Trifluoperazine\#Uses

2) Se-Young C., Young-Sang K., Su-Hyun J., J. Pharmacol. Exp. Ther., 313 (2005), 888-95.

3) "British Pharmacopoeia", vol. 7 (2000) part 65-2.

4) Basavaiah K. and Krishnamurthy G., Talanta, 47, 59-66, (1998). 
5) Basavaiah K. and Krishnamurthy G., Mikrochim. Acta, 130, 197201, (1999).

6) Walash M. I., Rizk M., Abou-Ouf A. M. and Belal F., Analyst, 108, 626-632, (1983).

7) Walash M. I., Rizk M., Toubar S. S., Ahemed S. M. and Zukhari N. A., Bul. Fac. Pharm. (Cairo Univ.), 34, 71-75, (1996).

8) Basavaiah K. and Ramappa P. G., Indian J. Pharm. Sci., 47, 125127, (1985).

9) Basavaiah K. and Krishnamurthy G., Anal. Lett., 31, 1037- 46, (1998).

10) Singh S., Shukla I. C. and Shukla S., Indian J. Pharm. Sci., 50, 278$279,(1988)$.

11) Basavaiah K. and Krishnamurthy G., Ann. Chim. (Rome), 89, 623$629,(1999)$.

12) Basavaiah K., Krishnamurthy G. and Swamy J. M., East. Pharm., 41,107-109, (1999).

13) El-Kerdawy M. M., Hassan S. M. and El-Ashry S. M., Mikrochim. Acta., 108,323-328, (1992).

14) Zhang H., Kang Q. and Liu Y., Yaowu Fenxi Zazhi, 13, 124-125, (1993).

15) Sajjan A. G., Seetharamappa J. and Melwanki M. B., Indian J. Pharm. Sci., 63, 61-64, (2001).

16) Mohmed F. A., Anal. Lett., 28, 2491-2501, (1995).

17) Perez-Ruiz T., Martinezo-Lozano C., Thomas V. and Cardona C. S, Talanta, 40, 1361-1365,(1993).

18) Kojlo A., Anal. Lett., 30, 2553-2563, (1997).

19) Fox A. R. and McLonghlin D. A., J. Chromatogr., 631, 255-261, (1997).

20) Pournaghi Azar M. H and Farhadi Kh, Talanta, 44, 773-1781, (1997).

21) Lima J. L., Motenegro M., Conceicao B. S., Sales M. and Goreti F., J. Pharm. Sci., 86, 1234-1238, (1997).

22) Biryol I., Senturk Z., Ozkan S. A., Dermis S. and Uslu B., Port. Electrochim. Acta., 15, 5-15, (1997).

23) Senturk Z., Ozkan S. A., Uslu B. and Biryol L., J. Pharm. Biomed. Anal., 15,365-370, (1996).

24) Long L. and Zhang Y., Yaowu Fenxi Zazhi., 1 45-46, (1995).

25) Lopez Paz J. J. and Townsend A., Anal. Commun., 33, 31-33, (1996).

26) Alwarthan A. A., Al-Tamrah S. A. and Akel A. A., Anal. Chim. Acta, 282,169 -174, (1993).

27) Job. P., "Spectrochemical Methods of Analysis", Wiley Intersience: New York, p. 346 (1971).

28) Christian G. D., "Analytical Chemistry", fifth ed., Wiley, New York, (1994), pp. 385-386. 